\title{
The Constitution Act, 1982 and the Crown: Twenty-Five Years Later
}

\section{Kenneth Munro*}

In a splendid ceremony on Parliament Hill on 17 April 1982, Her Majesty proclaimed the Constitution Act, 1982. ${ }^{1}$ When the Prime Minister and premiers had met in November 1981 to develop procedures for patriating and amending our Constitution, they failed to propose any revisions with respect to the monarchy, except for section 41(a) of the Constitution Act, 1982. Under this section, the unanimous agreement of the Governor General, Senate, House of Commons, and the legislative assembly of each province is required to amend the Constitution in relation to "the office of the Queen, the Governor General and the Lieutenant Governor of a province." 2 In effect, by entrenching the monarchy in the Constitution, our leaders determined that Canada would remain a constitutional monarchy in perpetuity. The twenty-fifth anniversary of the proclamation of the Constitution Act, 1982 provides an appropriate occasion to remind ourselves of the nature of our Canadian Crown and to ask whether this institution can evolve, or has evolved, to meet the needs of $\mathrm{Ca}$ nadians.

The Canadian Crown, the only constitutional monarchy in all of continental America except for Belize, is made manifest in a team of persons: the first is the monarch who lives outside the country. We share the person of our Queen with fifteen other countries. ${ }^{3}$ She has unfailingly carried out her role, rooted in Canadian tradition and experience, albeit shared with members of the Commonwealth of Nations of which she is the Sovereign.

The second element of the Canadian Crown is the Governor General, who resides in Ottawa and exercises all prerogatives of the Crown within the federal sphere of jurisdiction. The third element consists of the ten Lieutenant-Governors who reside in their respective provincial capitals and exercise the prerogatives of the Crown within the provincial sphere. While sovereignty is divided within Canada between federal and provincial jurisdictions, ${ }^{4}$ the Queen combines the two in her own person, giving unity to these three elements of our Maple Crown.

Any discussion about the Crown over the past twenty-five years would naturally examine the powers of the Crown which are derived from two sources: statute and common law. ${ }^{5}$ Parliament has conferred wide powers on our Crown to administer and to legislate. Since these are delegated powers, they are subject to change by Parliament. ${ }^{6}$ We often think that the monarch holds office because of hereditary right, but this is not the case. Since the Glorious Revolution in Britain in 1688, the Sovereign holds office at the will of Parliament. In addition, since the Statute of Westminster ${ }^{7}$ was passed in 1931, Canada has had a role in the selection of its monarch because that statute reads:

[A]ny alteration in the law touching the Succession to the Throne or the Royal Style and Titles shall hereafter require the assent as well of the Parliaments of all the Dominions as of the Parliament of the United Kingdom. ${ }^{8}$

Indeed, the Parliament of Canada changed the royal style and title of our Sovereign under the Royal Style and Titles Act of 1953, ${ }^{9}$ thereby making the Queen, on 28 May 1953, officially Queen of Canada. 
Several powers were specifically granted to the Sovereign in the Constitution Act, $1867,{ }^{10}$ and the amendments made in the Constitution Act, 1982 did not change these powers. For example, the Queen authorizes the Governor General to appoint deputies, she is commander-in-chief of the armed forces, and she decides where the national capital is to be located. In addition, Parliament consists of the Queen, the Senate, and the House of Commons; the Queen may appoint Senators; Royal Assent is given in the Queen's name; and the Queen may admit new provinces and territories. ${ }^{11}$

Even though no modification was made by statute to the institution of the Crown in 1982, the powers exercised by the Governor General, in particular, have changed over the past twenty-five years. The Governor General's duties have expanded and the powers have increased, not because of the legislated changes embedded in the Constitution Act, 1982, but because several Governors General and their respective governments have interpreted the Letters Patent Constituting the Office of Governor General of Canada (Letters Patent) in the broadest possible manner. In her memoir, Adrienne Clarkson wrote that:

\section{Even many politicians don't seem to know that the final authority of the state was transferred from the monarch to the Governor General in the Letters Patent of 1947, thereby making Canada's government independent of Great Britain. This means that it is the Governor General who is the guarantor of responsible government and of our parliamentary democ- racy. ${ }^{12}$}

The Letters Patent was issued on 1 October 1947 by King George VI, and conferred on the Governor General "all powers and authorities lawfully belonging to Us in respect of Canada." ${ }^{13}$ Former Governors General and constitutional scholars have focused on this phrase. Jules Léger has written that since 1947, "the Governor General had been authorized to exercise all the powers and authorities of the Sovereign with regard to Canada, but in practice, a few official acts ... had continued to be performed by the Sovereign." 14 Likewise, the noted constitutional authority, James R. Mallory, has pointed out that legally "the Governor General can exercise any of the Queen's powers in Canada." ${ }^{15}$ The converse is not true, however; "the Queen cannot exercise the Governor General's powers because they are conferred on him, and not on the Queen, by the British North America Act." ${ }^{16}$ Where a function is purely ceremonial or does not require the production of some instrument of lawful effect, the Queen can officiate; otherwise, she cannot unless Parliament passes a royal powers act similar to the one passed in Australia in 1973. ${ }^{17}$ Therefore, the Queen might give Royal Assent to legislation at the federal level or open Parliament, but she could not approve an order-in-council or effectively replace the Governor General during a royal visit. ${ }^{18}$

While the Letters Patent purports to delegate all royal powers in relation to Canada to the Governor General, Mallory has noted an apparent "understanding at the time that all matters which prior to that time had been based on direct advice to the Sovereign would not be transferred to the Governor General without the consent of the Palace."19 However, over the years, Canadian governments have sought and received the Sovereign's consent to transfer a great deal of the Queen's remaining power to the Governor General. For example, with the establishment of the Order of Canada in 1967 and the Order of Military Merit in 1972, the Queen became the Sovereign of these orders, ${ }^{20}$ while the Governor General became the chancellor of these two Canadian orders with their respective chancelleries and the secretary of the Canadian system of honours housed at Rideau Hall. ${ }^{21} \mathrm{Al}-$ though state visits by Governors General predate the issuance of the Letters Patent (Lord Willingdon made a state visit to Washington in 1928), ${ }^{22}$ these visits have become, since the days of Governor General Roland Michener, an important function performed by the Governor General rather than the Queen. While statute dictates that the Governor General must seek the Queen's consent to travel outside Canada, ${ }^{23}$ the Queen has encouraged her Governors General to pressure the Canadian government into letting them undertake such state visits. In his biography of Michener, Peter Stursberg claims that Michener told him that the Queen encouraged him to go abroad on visits as Canada's 
head of state. In conversation with Michener, the Queen said:

I go abroad representing the Commonwealth but I'm always accepted as the Queen of the United Kingdom. I can't represent Canada on these state visits. I think that you should, in your role [as Governor General], encourage your Government to send you on these visits. $^{24}$

He did just that and so did subsequent Governors General. In these and other areas, the Canadian government, the Queen, and the Governor General have worked together to expand the interpretation of the Letters Patent to enlarge the role of the Governor General. Other examples abound.

Jules Léger claimed that after "her visit in October 1977, Her Majesty agreed that certain diplomatic functions be 'repatriated' to Canada." ${ }^{25}$ Consequently, new arrangements related to diplomatic appointments and the various exchanges connected with them were made in 1977. At that time, it was agreed that the Governor General, not the Queen, would appoint and recall ambassadors accredited to foreign states (High Commissioners to other Commonwealth countries had always been appointed by the Governor General). However, the relevant diplomatic letters - Letters of Credence - were revised to begin: "On behalf of and in the Name of Elizabeth II." In similar fashion, the letters accrediting diplomats to Canada continued to be written to the Queen. Once they were accepted by the Governor General, they would be forward, unopened, to Her Majesty who would peruse them before returning them to Canada and the foreign affairs department. This procedure "did codify what had been envisaged by the Letters Patent for the Governor General as written in 1947 but which to that time had not been fully implemented." ${ }^{26}$ In addition, the Governor General would deal with the acceptance of Letters of Recall of foreign ambassadors and the approval of the establishment or severance of diplomatic relations between Canada and foreign states. ${ }^{27}$ The Queen also agreed that should it be necessary, "the Governor General would sign Declarations of War and other international documents, on Her Majesty's behalf." 28
During the royal visit to Edmonton in the summer of 1978, Prime Minister Pierre Trudeau discussed his proposal for constitutional reform with the Queen. A few months before, the minister of justice, the Honourable Ron Basford, had gone to London to present the proposed changes to the Queen, who "was quite happily satisfied that nothing would be changed in the Crown's essential relation to Canada." ${ }^{29}$ With the Queen's approval, the government proposed a White Paper, and then legislation in 1978, which modified the Crown's statutory position in Canada.

Trudeau's June 1978 White Paper on constitutional change $-A$ Time for Action ${ }^{30}$ - was followed by detailed draft legislation: Bill C$60 .{ }^{31}$ Editorial comment in the English press in Canada focused on what Trudeau was trying to do to the Queen. As Richard Gwyn noted: "By raising the Governor General to the new status of 'First Citizen' of Canada, who would open and dissolve Parliament in his own name rather than in Hers, Trudeau appeared to be trying to downgrade her." 32 In effect, Bill C-60 would have retained the monarchy for Canada and constituted "at the same time, a Governor General with full status and powers in his or her own right rather than merely in the capacity of a representative of the Sovereign." ${ }^{33}$

Under Bill-60, the Governor General "would see his authority derived from the constitution and not from the monarchy." ${ }^{34}$ In effect, the Governor General would exercise his authority in his own right rather than in the name of the Queen; at the same time, "the Queen would remain the Sovereign but would exercise authority only while she is in Canada." 35 Some journalists opposed this change. Charles Lynch, for example, expressing his concern in the Ottawa Citizen ${ }^{36}$ indicated his preference for retaining the wording of the Constitution Act, 1867, which states: "There shall be One Parliament for Canada, consisting of the Queen, an Upper House styled the Senate, and the House of Commons." ${ }^{37}$ Under Bill C-60, this section would have been changed to read: "There shall be one Parliament for Canada, consisting of the Governor General of Canada, an upper house styled the House of the Federa- 
tion, and the House of Commons." ${ }^{38}$ The Queen would be called " $t$ ]he sovereign head of Canada" 39 and styled "the Queen of Canada." ${ }^{30}$ In turn, the bill declares that " $[\mathrm{t}]$ he executive government of and over Canada shall be vested in the Governor General, on behalf of and in the name of the Queen," ${ }^{31}$ and that "The Governor General of Canada shall have precedence as the First Canadian, and the office of the Governor General shall stand above and apart from any other public office in Canada." ${ }^{2} 2$ The Constitution Act, 1867 states that the "Command-inChief of the Land and Naval Militia, and of all Naval and Military Forces, of and in Canada, is hereby declared to continue and be vested in the Queen." ${ }^{33}$ Bill C-60 would have effected a change to read: "[The] command-in-chief of the Canadian Forces is hereby declared to be vested in the Governor General of Canada." 44

In addition to the Queen and the Governor General, the Trudeau government's Bill C-60 - like the proposed constitutional amendments in the Canadian Constitutional Charter, 1971 (Victoria Charter) - made reference to the Lieutenant Governors of Canada. At Victoria in 1971, the federal government under Trudeau had proposed the repeal of the powers of reservation and disallowance. ${ }^{45}$ These constitutional amendments, proposed in the Victoria Charter, ${ }^{46}$ would not have affected the office of Lieutenant Governor in each province. ${ }^{47}$ Nevertheless, the effect of a constitutional amendment repealing the powers of reservation and disallowance would have been to radically diminish the Governor General's - and by convention the federal government's - control over the Lieutenant Governors and therefore the provincial governments. The package of constitutional changes in the Victoria Charter was first accepted by all the premiers, but was subsequently rejected by Québec for reasons other than this particular constitutional item. Many Canadians agreed with Trudeau when he stated that "The Victoria Charter would have been good for all Canadians: the federal government would have given up the powers of reservation and disallowance."48 Again, under Bill C-60 the Trudeau government proposed to repeal the clauses in the Constitution dealing with reservation and disallowance. ${ }^{49}$ However, as with the Victoria
Charter, this attempt at extensive constitutional change failed and thus any legislative change to the Crown failed with it.

When Prime Minister Trudeau again attempted to change the Constitution and patriate it in 1978, eventually succeeding in 1982, the Crown was not affected by the resultant Constitution Act, 1982, and the status quo position of the Crown was entrenched with an onerous amendment procedure requiring unanimity. There is irony in the Trudeau government attempting to make major changes to the Crown, but eventually entrenching it in 1982 with "the strongest constitutional position it has yet had." ${ }^{50}$ After all, there was an unusual provincial consensus on the constitutional amendments of 1982 (with the exception of the province of Québec), but the opportunity to address the powers of the Crown was not taken up; the existing powers exercised by the Queen remained intact. For example, in 1990, in order to pass the goods and services tax legislation (GST) through an obstructionist Liberal Senate, the Conservative government was able to ask the Queen, through the Governor General, to use her power to summon extra Conservative Senators under section 26 of the Constitution Act, 1867. As former prime minister Brian Mulroney explained in his autobiography, as soon as he had heard that the Liberal leader, Jean Chrétien, was going to have Liberal Senators kill the GST, he began to implement a plan which had been initiated over the summer months of 1990 :

We contacted Balmoral Castle, where the Queen was in residence, to get her approval, and Marj LeBreton began calling the new senators across the country to ensure their presence the following day for their swearing-in. ${ }^{51}$

While the Queen still exercises some powers stipulated in the Constitution, the appointment of extra Senators for example, federal governments continue to use the Letters Patent to increase the powers and position of the Governor General. In late December 2004, the palace and the Paul Martin government agreed that henceforth, even Letters of Credence to Canadian ambassadors would be issued in the name of the Governor General. ${ }^{52}$ Again, between 1977 and late 2004, Letters of Credence given 
to our ambassadors travelling abroad were issued "In the Name of and on Behalf of Elizabeth II." The Martin government, however, removed the Queen's name from these diplomatic letters by which ambassadors are exchanged, using instead the name of the Governor General. This procedure has been criticized for giving the appearance of replacing Elizabeth II as our head of state with the Governor General. ${ }^{53}$ Indeed, for many years journalists and broadcasters have contributed to the confusion and fuss about who is, in fact, the Canadian head of state. In his biography on Michener, for example, Stursberg refers to the Governor General as the Canadian head of state in his discussion of the regular meetings between prime minister as head of government and Governor General as head of state. ${ }^{54}$ Indeed, present and previous Governors General have contributed to this concern that the Governor General has been elevated to the role of head of state of Canada. Adrienne Clarkson stated with precision in her memoir that "the Governor General is the head of state in Canada, and is treated as such when abroad." 55 The present Governor General, Her Excellency Michaëlle Jean, has adopted a somewhat different position, preferring instead to refer to the Governor General as Canada's "de facto head of state." ${ }^{\prime 6}$

Attempts to enhance the role of the Governor General in Canadian public life might well also raise questions about the position of the Lieutenant Governors in the provincial sphere. Since the Constitution Act, 1982 did not change the constitutional powers of the Canadian Crown, the Governor General, for example, continues to have the authority to disallow provincial legislation despite assent by a Lieutenant Governor. Controversy and conflict could envelope the Canadian Crown in the future as Lieutenant Governors attempt to assert their authority in the provincial sphere of jurisdiction vis-à-vis a more demanding and more assertive Governor General at the federal level.

If the power of disallowance is to be used again, it is likely to be used by the Governor General (on the advice of the prime minister) against a hostile provincial administration. The last time it was used was with respect to Alberta legislation which, the federal government felt, threatened banking and mortgage credit. The action by the Governor General was upheld by the Supreme Court in $1938 .{ }^{57}$ The federal government has since shown no disposition to use these powers (as it might have in the case of the Quebec Charter of the French Language ${ }^{58}$ in 1977) preferring instead to have the courts deal with constitutional issues. Nevertheless, as Mallory has pointed out, reservation and disallowance "may be used as a trade-off in federalprovincial bargaining over larger constitutional change." 59

Canadians have yet to sort out the exact role they wish the Lieutenant Governors to play visà-vis the Governor General and the Sovereign herself. Thus, although the role of the Crown has, since 1982, evolved through a generous interpretation of the Letters Patent rather than statutory law, failure to address the role of the Lieutenant Governors with respect to the other two aspects of the Canadian Crown - the Monarch and Governor General - could result in controversy which will not serve the institution of the Canadian Crown well.

While the Constitution Act, 1982 did not clarify the power and role of the LieutenantGovernors vis-à-vis the Governor General, and while the power and authority of the Governor General has increased over the past twentyfive years through a more expansive interpretation of the Letters Patent, a more pressing concern remains: preventing prime ministers and premiers from abusing the Crown's reserve powers. ${ }^{60}$ When granted to Canada in 1848, responsible government implied that the Governor General "would act on the advice of his ministers under normal circumstances." ${ }^{\prime 1} \mathrm{Nev}-$ ertheless, in the early years of Confederation the Governor General was "required to refuse assent to or reserve for the scrutiny of Britain's government any Canadian legislation that was contrary to any imperial statute which extended in its operation to Canada." 62 Although the latter requirement was eliminated through the Balfour Declaration of 1926 and codified in the 1931 Statute of Westminster, ${ }^{63}$ responsibility for safeguarding the constitution remained with the Governor General, who would now 
normally act solely on the advice of his or her Canadian ministers. Armed with the royal prerogative, including the reserve powers, the Governor General had henceforth to resolve any conflict between her duty to act on the advice of her ministry, and her duty to safeguard the constitution. A danger to our monarchical system, and to our unwritten or conventional constitution, arises when a prime minister advises the Governor General to use the royal prerogative for partisan political advantage.

In 1926, Governor General Lord Byng, exercising the royal prerogative, denied the request of his Liberal prime minister, William Lyon Mackenzie King, to dissolve Parliament so that a general election might be held. King had made the request because the Liberals, caught up in a customs department scandal, faced certain defeat. Under our system of responsible government, the prime minister has the right to make such a request. Controversy quickly erupted, however, when the Governor General, using the reserve powers of the Crown, refused King's request. King resigned without advising the Governor General on the choice of successor as prime minister. Fortunately, Arthur Meighen, the Conservative leader, agreed to become prime minister and thus take responsibility for the Governor General's actions. King won the subsequent election, calling into question the Governor General's disregard of his advice. Indeed, the effect of the "King-Byng" affair on Canadians' perception of the legitimacy of the reserve powers of the Crown remains with us. Errol Mendes, for example, has recently written that although the Governor General "has an uncontested residual power to deny a prime minster's request for dissolution," but because of the 1926 precedent a Governor General's refusal "to grant the request of a prime minister for dissolution, no matter how contrived,"64 would present a serious political problem for the Governor General.

The noted specialist on the Canadian Crown, David Smith, has provided several examples of prime ministerial abuse of the royal prerogative in the past. ${ }^{65}$ Recently, Prime Minister Stephen Harper has provided another such example. Implementing its Conservative 2006 election platform promise of a fixed general election date, the Conservative government set the next election date for October $2009^{66}$ to prevent "leaders from trying to manipulate the calendar simply for partisan political advantage." 67 The subsequent violation of this law by the Conservative government in September 2008 was most disgraceful since Parliament was to reconvene within two weeks of the Prime Minister hastily asking the Governor General for a dissolution. A nonconfidence vote in the House of Commons might yet have brought down the government and forced an election, but Harper refused to await a decision of the House of Commons. Harper's actions exposed the Governor General to political speculation and controversy.

Although the Conservative government used statute law to "constrain the conventional power of the prime minister to seek dissolution whenever he smelled political advantage to do so," 68 the legislation did not remove the reserve powers of the Governor General. The law explicitly stated: "Nothing in this section affects the powers of the Governor General, including the power to dissolve Parliament at the Governor General's discretion." ${ }^{69}$ By relying on the latitude given by this clause in determining for himself the timing of the election, Prime Minister Harper not only offended the basic political morality of Canadians, but besmirched the office of the Governor General.

While constitutional experts agree that a Governor General is not empowered to dissolve Parliament without advice, ${ }^{70}$ not all of them believe that Governor General Jean was required to accept Stephen Harper's advice to dissolve Parliament on 7 September 2008. Michael Biehels, for example, has suggested that the Governor General would have provoked "a manufactured constitutional crisis" by not accepting her Prime Minister's advice to dissolve Parliament. Because his actions violated the fixed election law, Biehels argues, accepting the Prime Minister's advice would, in fact, be "helping to undermine the rule of law." ${ }^{\prime 1}$

A controversy still exists regarding whether the King-Byng affair of 1926 set a constitutional convention whereby a Governor General must accept the advice of a prime minister request- 
ing dissolution. Adrienne Clarkson has argued that the power of the Governor General to refuse dissolution exists, but "it would be justified only in the most exceptional of circumstances." ${ }^{\prime 2}$ She notes that if a government were to last six months, she would grant a prime minster a dissolution, but:

To put the Canadian people through an election before six months would have been irresponsible, and in that case I would have decided in favour of the good of the Canadian people and denied dissolution. ${ }^{73}$

In 1982, former Governor General Edward Schreyer mused in a similar fashion. In an interview with Canadian Press, he said that "he would have stepped in and ordered an election if Prime Minister Pierre Trudeau had tried to push through his constitutional plans despite continued provincial opposition." 74 This statement met with a sharp rebuke from noted midcentury constitutional expert Eugene Forsey, who called it "appalling," "dreadful," and "indiscreet beyond belief." ${ }^{\prime \prime}$ On the other hand, Mallory argued that the Governor General would have been acting within his powers since "A governor-general has the power to dismiss a prime minister, in effect forcing an election." ${ }^{\prime \prime}$ Whatever the case, it is a mistake for a prime minister to place a Governor General in a position which invites controversy over the use of the reserve power of the Crown for partisan advantage.

In looking back over the past twenty-five years since the Constitution Act, 1982 was proclaimed by the Queen that historic April day on Parliament Hill, the monarchy has continued to play a pivotal role at the very centre of our constitution. While the institution was entrenched in the 1982 Constitution, and the role of the Governor General expanded using powers granted in the Letters Patent rather than the constitutional amendment procedures, there are disquieting signs that the reserve powers of the Crown can be used by power-lusting prime ministers and premiers for their own partisan advantage. Consequently, the Governor General and Lieutenant-Governors must be very wary and wise in using the royal prerogative to protect the Constitution. This undertaking is not easy in our system of responsible government in Canada, as politicians attempt to use the Crown's reserve powers in their pursuit of political power.

\section{Notes}

* Kenneth Munro, Department of History, University of Alberta. An earlier version of this article was presented to the conference entitled: The $25^{\text {th }}$ Anniversary of the Canadian Constitution: Perspective from the West/25e anniversaire de la Constitution canadienne: perspectives de l'Ouest canadien, Campus Saint-Jean, Edmonton Alberta, 23 November 2007.

1 Constitution Act 1982, being Schedule B to the Canada Act 1982 (U.K.), 1982, c. 11 (CanLII).

2 Section 41 outlines those areas of the Constitution which require unanimous consent for amendment: "An amendment to the Constitution of Canada in relation to the following matters may be made by proclamation issued by the Governor General under the Great Seal of Canada only where authorized by resolutions of the Senate and House of Commons and of the legislative assembly of each province: (a) the office of the Queen, the Governor General and the Lieutenant-Governor of a province."

3 The United Kingdom, Antigua and Barbados, Australia, The Bahamas, Barbados, Belize, Grenada, Jamaica, New Zealand, Papua New Guinea, St Christopher and Nevis, St. Lucia, St. Vincent and the Grenadines, Solomon Islands, and Tuvalu. Juliet O’Neill, “Battle Royal” Edmonton Journal (29 September 2002) D10.

4 The question of sovereignty has been complicated by the recognition of Aboriginal self-government. See Campbell et al v. Nisga'a, 2000 BCSC 619 (CanLII).

5 James R. Mallory, The Structure of Canadian Government, revised ed. (Toronto: Gage Educational Publishing Company, 1984) at 34.

$6 \quad$ Ibid.

$7 \quad$ Statute of Westminster 1931, (U.K.) 22 \& 23 Geo. V, c. 4, s. 2 (BAILII).

$8 \quad$ Ibid. at preamble.

9 R.S.C. 1985 , c. R-12. See Mallory, supra note 5 at 36.

10 (U.K.), 30 \& 31 Vict., c. 3, reprinted in R.S.C. 1985, App. II, No. 5 (CanLII).

11 Fidelis, "A Very Alarming Situation: the New Threat to the Canadian Monarchy - What Next?" (Spring 2005) 23 Canadian Monarchist News/Les 
Nouvelles Monarchiques du Canada at 3 [Fidelis, "Alarming Situation"]. These powers are found in sections 14, 15, 16, 17, 26, 55, 56, 57 and 146 of the Constitution Act, 1867, supra note 10. See J.L. Finlay \& D.N. Sprague, The Structure of Cana-

dian History 5th ed. (Scarborough, ON.: Prentice Hall Allyn and Bacon Canada, 1997) at 604, 607, 617-18 and 146.

12 Adrienne Clarkson, Heart Matters: a Memoir (Toronto: Viking Canada, 2006) at 189-90.

13 The key sections of the Letters Patent of 1947 read:

II. And We do hereby authorize and empower Our Governor General, with the advice of Out Privy Council for Canada or of any members thereof or individually, as the case requires, to exercise all powers and authorities lawfully belonging to Us in respect of Canada, and for greater certainty but not so as to restrict the generality of the foregoing to do and execute, in the manner aforesaid, all things that may belong to his office and to the trust We have reposed in him according to the several powers and authorities granted or appointed him by virtue of the Constitution Acts, 1867 to 1940 and the powers and authorities hereinafter conferred in these Letters Patent and in such Commission as may be issued to him under Our Great Seal of Canada and under such laws aw are or may hereinafter be in force in Canada.

IV. And WE do further authorize and empower Our Governor General to constitute and appoint, in Our name and on Our behalf, all such Judges, Commissioners, Justices of the Peace, and other necessary Officers (including diplomatic and consular officers) and Ministers of Canada, as may be lawfully constituted or appointed by Us.

Jules Léger, Jules Léger: Gouverneur Général du Canada/Governor General of Canada 1974-1979 (Montréal: La Presse, 1982) at 214.

Mallory, supra note 5 at 37.

Ibid.

Royal Style and Titles Act 1973 (Cth) (AustLII).

Mallory, supra note 5 at 37.

Ibid.

Christopher McCreery, The Canadian Honours System (Toronto: Dundurn Press, 2005) at 60.

Jacques Monet, "Jules Léger: the Man and the Mandate" in Léger, supra note 14 at 14 and 22. Léger, supra note 14 at 224.

Fidelis, "Alarming Situation," supra note 11 at 2. Peter Stursberg, Roland Michener: The Last Viceroy (Toronto: McGraw-Hill Ryerson, 1989) at 164. Adrienne Clarkson quotes this passage from Stursberg's book in her autobiography. See Clarkson, supra note 12 at 194.

Léger, supra note 14 at 214.

Fidelis, "Alarming Situation," supra note 11 at 2. Mallory, supra note 5 at 38.

Fidelis, "Alarming Situation," supra note 11 at 2.
29 Léger, supra note 14 at 216.

30 Pierre Elliott Trudeau, A Time for Action: Towards the Renewal of the Canadian Federation (Ottawa: Government of Canada, 1978).

31 Bill C-60, An Act to amend the Constitution of Canada with respect to matters coming within the legislative authority of the Parliament of Canada, and to approve and authorize the taking of measures necessary for the amendment of the Constitution with respect to certain other matters, 3rd Sess., 30th Parl., 1978 (as introduced 20 June 1978) [Constitutional Amendment Act, 1978].

32 Richard Gwyn, The Northern Magus: Pierre Trudeau and Canadians (Toronto: McClelland \& Stewart, 1980) at 268.

33 Canada, The Constitutional Amendment Bill: text and explanatory notes (Ottawa: Government of Canada, 1978) at 16 [Constitutional Amendment Bill]. See Bill C-60, supra note 31, sections 42-48.

34 Editorial, The Ottawa Citizen (22 June 1978) 6.

35 John Gray, "Constitutional Reforms Unveiled: Language Rights high on list" The Ottawa Citizen (21 June 1978) 1.

36 Charles Lynch, "'Cure' worse than the disease" The Ottawa Citizen (22 June 1978) 7.

37 Supra note 10 at section 17.

38 Bill C-60, supra note 31 at section 56.

39 Ibid. at section 30.

40 Ibid.

41 Ibid. at section 43.

42 Ibid. at section 44.

43 Supra note 10 at section 15.

44 Supra note 31 at section 47.

45 For the constitutional provisions referring to reservations and disallowance, see Constitution Act, 1867, supra note 10 at sections 55-57.

46 Victoria Charter, Part X - Modernization of the Constitution, article 59. The amendments would have affected part of sections 55 and 90, and all of sections 56 and 57 of the Constitution Act, 1867, supra note 10.

47 Victoria Charter, Part III - Provinces and Territories, article 21 (declaring the retention of the office of Lieutenant Governor).

48 Pierre Elliott Trudeau, Memoirs (Toronto: McClelland \& Stewart, 1993) at 231.

49 Bill C-60, supra note 31 at sections $42-48$ and 7984; see Gray, supra note 35 at 1.

50 Norman Ward, Dawson's The Government of Canada, 6th ed. (Toronto: University of Toronto Press, 1987) at 193-94.

51 Brian Mulroney, Memoirs 1939-1993 (Toronto: McClelland \& Stewart, 2007) at 813.

52 Fidelis, "The Clarkson-Saul Years at Rideau Hall" (Fall/Winter 2005) 24 Canadian Monarchist 
News/Les Nouvelles Monarchiques du Canada at 7.

53 Fidelis, "Alarming Situation," supra note 11 at 1.

54 Stursberg, supra note 24 at 202.

55 Clarkson, supra note 12 at 200.

56 Governor General of Canada, Media Release, "Media

For the First Time, a Head of State is Officially

Welcomed at the Governor General's Residence at the Citadelle: One of the Highlights of the Governor General's Program During Her Stay in Quebec City from September 18 to 24, 2006” (18 September 2006).

Reference re Alberta Statutes, [1938] S.C.R. 100. R.S.Q. 1977, c. C-11.

Mallory, supra note 5 at 370.

60 David E. Smith, The Invisible Crown: The First Principle of Canadian Government (Toronto: University of Toronto Press, 1995) at 43. The Governor General's reserve powers arguably include at least the power to appointment and dismiss the prime minister and to dissolve Parliament.

61 Barbara J. Messamore, Canada's Governors General, 1847-1878: Biography and Constitutional Evolution (Toronto: University of Toronto Press, 2006) at 25.

62 Ibid. at 25-26.

63 Ibid. at 27.

64 Errol P. Mendes, "Harper's snap election call would violate 'principle' he fought for: It will take some twisted rhetoric to justify breaking with fixed election date" Edmonton Journal (29 August 2008) A16.

65 Supra note 60 at 57.

66 Canada Elections Act, S.C. 2000, c. 9, s. 56.1(2), as enacted by An Act to amend the Canada Elections Act S.C. 2007 , c. 10.

67 "Harper promises law to set election date every four years," online: CBC News (26 May 2006) $<$ http://www.cbc.ca/canada/story/2006/05/26/ fixed-vote-060526.html>.

68 Mendes, supra note 64.

69 Canada Elections Act, supra note 66 at section 56.1(1).

70 Smith, supra note 60 at 59.

71 Michael D. Behiels, "Michael D. Behiels The PM and the law," online: Ottawa Citizen (5 September 2008) <http://www.canada.com/ottawacitizen/news/opinion/story.html?id=87efb8e0-1adb457e-99ce-847a3815579c $>$ [emphasis added].

72 Clarkson, supra not 12 at 192.

73 Ibid.

74 "Could have called election, Governor-General says: Schreyer would have blocked forced patria- tion" The Globe and Mail (22 January 1982) 8.

76 Ibid. 